The International Indigenous Policy Journal

\title{
More Than Words: Outlining Preconditions to Collaboration Among First Nations, the Federal Government, and the Provincial Government
}

\section{Nathalie Lachance et Teresa Rose}

Volume 11, numéro 2, 2020

URI : https://id.erudit.org/iderudit/1071400ar

DOI : https://doi.org/10.18584/iipj.2020.11.2.10692

Aller au sommaire du numéro

Éditeur(s)

Scholarship@Western (Western University)

ISSN

1916-5781 (numérique)

Découvrir la revue

Citer cet article

Lachance, N. \& Rose, T. (2020). More Than Words: Outlining Preconditions to Collaboration Among First Nations, the Federal Government, and the Provincial Government. The International Indigenous Policy Journal, 11(2), 1-24. https://doi.org/10.18584/iipj.2020.11.2.10692
Résumé de l'article

Since 2015, there has been heightened interest in reconciliation and renewed relationships with Indigenous Peoples. Anchoring our work in the definition of reconciliation provided by the Truth and Reconciliation Commission of Canada, we, as practitioner-scholars, sought to better understand the preconditions to collaboration among First Nations, the federal government, and the provincial government in Alberta. This participatory action research was conducted with mid- to senior-level public servants, who were involved in the further development and implementation of the 2014 Joint Action Plan to Improve the Health of First Nations in Alberta, in either First Nations, the federal government, or the provincial government. This article concludes that collaboration must consider the negative legacy of relationships between First Nations and federal and provincial governments, as well as between First Nations and settlers.
Copyright (c) Nathalie Lachance, Teresa Rose, 2020

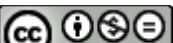

Ce document est protégé par la loi sur le droit d'auteur. L'utilisation des services d’Érudit (y compris la reproduction) est assujettie à sa politique d'utilisation que vous pouvez consulter en ligne. 


\section{More Than Words: Outlining Preconditions to Collaboration Among First Nations, the Federal Government, and the Provincial Government}

Nathalie Lachance

AthabascaUniversity,nlachance1@athabasca.edu

Teresa Rose

AthabascaUniversity, teresa.rose@fb.athabascau.ca

Recommended Citation

Lachance, N., \& Rose, T. (2020). More than words: Outlining preconditions to collaboration among First Nations, the federal government, and the provincial government. The International Indigenous Policy Journal, 11(2). doi: https://10.18584/ iipj.2020.11.2.10692 


\title{
More Than Words: Outlining Preconditions to Collaboration Among First Nations, the Federal Government, and the Provincial Government
}

\author{
Abstract \\ Since 2015, there has been heightened interest in reconciliation and renewed relationships with Indigenous \\ Peoples. Anchoring our work in the definition of reconciliation provided by the Truth and Reconciliation \\ Commission of Canada, we, as practitioner-scholars, sought to better understand the preconditions to \\ collaboration among First Nations, the federal government, and the provincial government in Alberta. This \\ participatory action research was conducted with mid- to senior-level public servants, who were involved in the \\ further development and implementation of the 2014 Joint Action Plan to Improve the Health of First Nations in \\ Alberta, in either First Nations, the federal government, or the provincial government. This article concludes that \\ collaboration must consider the negative legacy of relationships between First Nations and federal and provincial \\ governments, as well as between First Nations and settlers.
}

\section{Keywords}

First Nations, intergovernmental relations, health care collaboration, preconditions to collaboration, participatory action research, Health Services Integration Fund, practitioner-scholars

\section{Acknowledgments}

We most sincerely thank the participants of First Nations, the federal government, and the provincial government who so graciously shared their experiences.

\section{Disclaimer}

The views, statements, and conclusions expressed and the recommendations made in this article are entirely those of the authors and should not be construed as statements or conclusions of, or as expressing the opinions of, Indigenous Services Canada.

\section{Creative Commons License (c) (1) 99}

This work is licensed under a Creative Commons Attribution-Noncommercial-No Derivative Works 4.0License. 


\section{More Than Words: Outlining Preconditions to Collaboration Among First Nations, the Federal Government, and the Provincial Government}

Since the release of the final report of the Truth and Reconciliation Commission of Canada (TRC, 2015), federal, provincial, and municipal governments have outlined the need for reconciliation as well as their desire for renewed relationships with Indigenous Peoples. The TRC (2015) defined reconciliation as follows:

Reconciliation is about establishing and maintaining a mutually respectful relationship between Aboriginal and non-Aboriginal peoples in this country. In order for that to happen, there has to be awareness of the past, acknowledgement of the harm that has been inflicted, atonement for the causes, and action to change behaviour. (p. 6)

We are interested in that latter part-actions to change behaviour. While we believe there could be a range of actions aimed at reconciliation, we anchor our work in collaboration. Our interest in collaboration stems from our experiences as non-Indigenous practitioner-scholars who have worked with Indigenous Peoples for decades. We have worked in Indigenous organizations, as a consultant in an Indigenous program, and for a federal department dedicated to serving Indigenous Peoples. Collaboration was also the stated goal of the 2014 Joint Action Plan to Improve the Health of First Nations in Alberta, which is the focus of this article. Its goal was "to enhance collaboration between First Nations [organizations and governments of Treaties No. 6, No. 7, and No. 8], Health Canada [First Nations and Inuit Health Branch-Alberta Region], Alberta Health and Alberta Health Services to achieve quality of health services for First Nations peoples that is accessible, appropriate, acceptable, efficient, effective and safe" (Co-Management, 2014, p. 1).

In describing collaboration, many scholars highlight its three phases: preconditions, processes, and outcomes (Butterfield et al., 2004; Wood \& Gray, 1991). With this article, we focus on the first phasepreconditions to collaboration among First Nations, the federal government, and the provincial government. We seek to answer the following question: How are efforts to collaborate and engage in reconciliation thwarted by unattended preconditions?

\section{Literature Review}

Prior to examining preconditions to collaboration among First Nations, the federal government, and the provincial government, we provide an overview of collaboration literature as well as contextual information on intergovernmental relationships impacting health care collaboration.

\section{Defining Collaboration}

Wood and Gray (1991) stated, "collaboration occurs when a group of autonomous stakeholders of a problem domain engage in an interactive process, using shared rules, norms, and structures, to act or decide on issues related to that domain" (p. 146). They identified six elements within their definition. First, it acknowledges that stakeholders may have common or different interests in addressing a given issue. Second, it indicates that participating organizations maintain their decision-making authority. Third, by referring to an interactive process, Wood and Gray highlight the desire for change among stakeholders. With the fourth element, they highlight that shared rules, forms, and structures may or may 
not exist at the beginning of the collaboration. Fifth, Wood and Gray stress the stakeholders' commitment to action or to make decisions. Finally, they refer to the need for "the participants to orient their processes, decisions, and actions toward issues related to the problem domain that brought them together" (Wood \& Gray, 1991, p. 148).

Collaboration has three phases: preconditions, processes, and outcomes (Butterfield et al., 2004; Wood \& Gray, 1991). The preconditions phase is concerned with problem-setting (Gray, 1985; Logsdon, 1991), where interests, legitimacy, and interdependence of partnering organizations are recognized (Hardy \& Phillips, 1998; Logsdon, 1991; Weick, 2001), as well as where the authority and representativeness of members are assessed (Fawcett et al., 1995; Gray, 1985; Huxham \& Vangen, 2000; Hocevar et al., 2007; Westley \& Vredenburg, 1991). They describe the process phase as direction setting (Gray, 1985) or more ambiguously as the "black box" of collaboration (Gray \& Wood, 1991) as the steps leading from preconditions to outcomes are not explicitly stated. Some authors include elements identified as preconditions by other authors, such as confirming membership and clarifying decisionmaking processes (Roberts \& Bradley, 1991), coincidence of values (Gray, 1985), and advocacy for formalization of processes (Roberts \& Bradley, 1991; Westley \& Vredenburg, 1991). The outcomes are the results achieved by the collaboration. While Gray's earlier work suggests linearity of collaboration, her more recent work "highlights how meanings and power shift within the field as partners negotiate the rules and norms that govern the field" (Gray \& Purdy, 2018, p. 13). This more cyclical view aligns well with our experience as practitioner-scholars. As this article focuses on preconditions, we anchor our analysis on Gray's six preconditions to collaboration: identification of a requisite number of stakeholders; positive beliefs about expected outcomes; recognition of interdependence; perceptions of legitimacy amongst stakeholders; obtaining a legitimate, skilled convenor; and shared access and power (Gray, 1985).

\section{Relationships Among First Nations, the Federal Government, and the Provincial Government}

We understand that there are important legal and jurisdictional aspects to collaboration among First Nations, the federal government, and the provincial government. However, for this research, we are interested in the social, cultural, and political aspects of collaboration as our interest is in collaboration at the practitioners' level. Even with this narrowed focus, we acknowledge that many Indigenous scholars have documented both Canada's colonial past and its ongoing colonization of First Nations (Alfred, 2009; Corntassel et al., 2009; Corntassel, 2012; Coulthard, 2014; Little Bear et al., 1992; Martin et al., 2017; Patrick et al., 2017; Simpson, 2001, 2011).

To understand these political circumstances, we briefly examine the context provided by documents from the $19^{\text {th }}$ century: the Constitution Act (1867), the Indian Act (1876), and, as this research was conducted in Alberta, to three of the numbered treaties: Treaty No. 6 (1876), Treaty No. 7 (1877), and Treaty No. 8 (1899). In Section 91(24) of the Constitution Act (1867) responsibility for "Indians, and 
Lands reserved for the Indians"1 is assigned to the federal government, while Section 92(7) grants the provinces exclusive jurisdiction over "the establishment, maintenance, and management of hospitals, asylums, charities, and eleemosynary institutions in and for the Province, other than marine hospitals." In 1876, the federal government drafted the Indian Act to consolidate existing legislation. Records show that the Indian Act "rests on the principle, that the aborigenes are to be kept in a condition of tutelage and treated as wards or children of the State" (Department of the Interior cited in the Royal Commission on Aboriginal Peoples, 1996, p. 349). The Indian Act has been described as "providing the legislative base for Canadian government control over Indians” (Little Bear et al., 1992, p. xix).

The numbered treaties spoke of a different relationship between Indigenous nations and settlers. Grounding their work in international laws, Indigenous scholars highlight that the numbered treaties are agreements negotiated between sovereign nations (Alfred, 2009; Borrows, 2002; Cardinal \& Hildebrandt, 2000; Little Bear et al., 1992; Turpel, 1991; Venne, 1998). Further, Cardinal and Hildebrandt (2000), who conducted focus group sessions with Elders, wrote, "their view and understanding of the Treaties differed significantly and substantively from the written text of the Treaties" (p. 25). They link these differences to the worldviews of the signatories: "Non-Aboriginal understanding of treaties and the treaty process is shaped by its colonial history. The First Nations' perspective must be understood in the context of their worldviews" (Cardinal \& Hildebrandt, 2000, p. 1). For First Nations, the treaties "were understood as land-sharing agreements that assured First Nations the right to earn a living through continuing traditional ways of earning a living or by adopting new ways" (Cardinal \& Hildebrandt, 2000, p. 69).

While most Canadians understand health care as a provincial jurisdiction based on Section 92(7) of the Constitution Act, First Nations understand health care as a Treaty Right based on the Medicine Chest Clause included in Treaty No. 6 (1876), which states, "a medicine chest shall be kept at the house of each Indian Agent for the use and benefit of the Indians at the direction of such agent” (para. 25). First Nations people understood it to mean "the full benefits of medicare" (Taylor, 1985, p. 36). First Nations also requested a Medicine Chest Clause as part of the negotiations leading to Treaty No. 8 (1899). Federal delivery of health services to First Nations began in 1904 when the Department of Indian Affairs appointed a general medical superintendent (Health Canada cited in Brede, 2008). Management of health services for First Nations and Inuit was transferred to the Department of Health and Welfare upon its creation in 1945. Medical Services Branch (MSB) was established in 1962 (Health Canada cited in Brede, 2008) and renamed First Nations and Inuit Health Branch (FNIHB) in 2000.

Development and expansion of provincial health care systems began in the second half of the $20^{\text {th }}$ century. In 1967, the Hawthorn (1967) study stated, "the Indian should [not] be required to assimilate . .. in order to receive what he now needs nor at any future time" (p.6). The study advocated for the "right of Indians to be citizens plus" (Hawthorn, 1967, p. 6). In its 1969 White Paper, the federal government proposed "that services come through the same channels and from the same government

\footnotetext{
${ }^{1}$ In our work, we use the name of the specific nation (e.g., Cree, Blackfoot) when known. While we know the nation of most participants, we sought to protect their identity by using the more generic term First Nations in this article. In national and/or international contexts, we opted to use the term Indigenous Peoples (Vowel, 2016). When we refer to other sources, we respected the wording and capitalization used in the source document. More specifically, while we do not use the word "Indian," it has a legal connotation in Canada as it is included in both the Indian Act and the Constitution Act.
} 
agencies for all Canadians" (Government of Canada, 1969, p. 7). First Nations respond by declaring the proposed policy "a thinly disguised programme of extermination by assimilation" (Cardinal, 1999, p. 1) and a way for the federal government "to wash its hands of Indians entirely, passing the buck to the provincial governments” (Cardinal, 1999, p. 1). The Royal Commission on Aboriginal Peoples (1996) indicated that the federal government withdrew the White Paper but "its underlying philosophy seemed to animate federal policy for years to come" (p. 203). The 1974 Policy of the Federal Government Concerning Indian Health Services indicated that its provision is voluntary and not based on Treaty Rights (Health Canada cited in Brede, 2008). In its Indian Health Policy (Health Canada, 1979), the federal government "recognizes its legal and traditional responsibilities to Indians" (para. 2), while also highlighting the role of provincial governments in providing health care. Blackfoot scholar Leroy Little Bear and his colleagues (1992) identified both the reluctance of provinces "to accept financial responsibility for services to Indians" (p. xiii) and the reluctance of First Nations to accept this arrangement as " $[t]$ hey interpret it as part of the federal government's hidden agenda to abrogate its constitutional and treaty obligations to the Indian people" (pp. xiii-xiv). Over the last 30 years, there has been heightened interest in increasing First Nations control over health care (Health Canada, 1999) and opportunities for greater collaboration among First Nations, the federal government, and the provincial government (Co-Management, 1996; Government of British Columbia, Government of Canada, \& the Leadership Council representing the First Nations of British Columbia, 2006).

\section{Health Care Collaboration in Alberta}

Collaboration is not a new concept for First Nations organizations and governments in Alberta. One of the better-known collaborations is the Co-Management Agreement signed in 1996 by many, though not all, First Nations Chiefs in Alberta and the federal Minister of Health. At the time we conducted this research, 39 of the 47 First Nations governments in Alberta were signatories to the Co-Management Agreement. The Co-Management Agreement allows First Nations organizations and governments and First Nations and Inuit Health Branch-Alberta Region (FNIHB-AB) to co-manage the FNIHB-AB funding (Co-Management, 1996). Beyond the Co-Management Agreement, there are many formal and informal collaborations, including memorandums of understanding or joint committees between First Nations organizations or governments, and Alberta Health, Alberta Health Services, or FNIHB-AB, as well as practical approaches to increase access to provincial health care on-reserve (Health Canada, 2012).

The 2014 Joint Action Plan to Improve the Health of First Nations in Alberta was a province-wide health care collaboration involving First Nations, the federal government, and the provincial government. It was a two-page document outlining a new multilateral health care collaboration to unfold over an 18-month period, which ended as the Assembly of Treaty Chiefs decided to halt all trilateral discussions in February 2018. The Joint Action Health Plan included three objectives: strengthening relationships; increasing accessibility, coordination, and quality of health services; and increasing First Nations control of health services and programs (Co-Management, 2014). FNIHB's Health Services Integration Fund (HSIF) funded its further development and implementation, which was in turn influenced by three 2015 events. The first of these events was the release of the TRC's (2015) final report, which in Call to Action 18 highlights the impact of government policies on Aboriginal health outcomes. The second event was the election of the Alberta New Democrats in May 2015, after more than four decades of Progressive Conservative party rule; in its first Speech from the Throne, the 
provincial government stated, "we need to return to a respectful relationship with this land's indigenous peoples" (Alberta Government, 2015, para. 60). At the federal level of government, the election of the Liberal Party of Canada in October 2015 was the third event. In its inaugural Speech from the Throne, the federal government stated, "because it is both the right thing to do and a certain path to economic growth, the Government will undertake to renew, nation-to-nation, the relationship between Canada and Indigenous peoples, one based on recognition of rights, respect, co-operation and partnership" (Canada Governor General, 2015, p. 6). The similarity in agendas changed with the re-election of the Liberal Party of Canada at the federal level and the election of the United Conservative Party in Alberta in 2019.

\section{Methods}

This participatory action research was grounded in our experiences as practitioner-scholars. The first author (N.L.) was working with colleagues in First Nations, the federal government, and the provincial government to further develop and implement the Joint Action Plan to Improve the Health of First Nations in Alberta. During the research planning phase, she sought guidance from the Health CoManagement Committee. The Health Co-Management Committee had no objections and approved the research. Her employer, Health Canada, assessed potential conflicts of interest and found the research complied with their policy. In order to meet Athabasca University's ethical requirements and ensure cultural appropriateness, we also solicited input and feedback from a colleague at the Alberta First Nations Information Governance Centre who helped ensure respect for First Nations' processes, as well as the Ownership, Control, Access, and Possession $\left(\mathrm{OCAP}^{\circledast}\right)$ principles (First Nations Information Governance Centre, 2014). AFNIGC provided confirmation the protocol was appropriate and respectful, and they provided much valued guidance, including assisting me in obtaining First Nations resources and templates (Assembly of First Nations Quebec-Labrador [AFNQL], 2014; University of Manitoba Faculty of Health Sciences, 2013). The Athabasca University Research Ethics Board granted ethics approval. As part of the process, participants were assured anonymity and confidentiality and consent forms were developed based on an Indigenous research model (AFNQL, 2014). We also secured a research agreement with Alberta Health Services. Data collection and analysis were informed by qualitative and Indigenous research methodologies (AFNQL, 2014; Battiste, 2005; Brant Castellano, 2004; Creswell, 2008; Gaudet, 2014; Kovach, 2012; Simpson, 2001; Smith, 1999; Wilson, 2008).

Participatory elements included interviewees having the ability to shape the questionnaire, and the opportunity to request changes to their transcript, refer colleagues for interviews, provide input and feedback upon receipt of the summary of analysis shared with Wave 1 participants, participate in a focus group $(n=15)$ to guide analysis and dissertation writing, and comment on a summary of findings.

The interview guide consisted of open-ended questions that had been reviewed, pilot-tested, and received input from Indigenous and non-Indigenous participants. All interviews except one were audio recorded. We validated the findings through a focus group with members of the Joint Action Health Plan Working Group.

All 25 participants were mid- to senior-level leaders in First Nations, federal, or provincial governments or organizations. Of the participants interviewed, 17 are Indigenous. The gender distribution of participants was relatively equal: 13 women and 12 men. The average interview length was 65 minutes.

Published by Scholarship@Western, 2020 
The first author (N.L.) conducted all interviews, thus increasing consistency across interviews. We made 35 interview requests and conducted 25 interviews for a participation rate of $71 \%$. Wave 1 involved 21 participants. Membership in the Joint Action Health Plan Working Group and Steering Committee was never formalized so, as new colleagues started attending meetings, a second wave of interviews provided an opportunity to hear them. A second wave of interviews with 4 participants was conducted in the fall 2016 - 10 to 12 months after the first round of interviews.

In the examples provided in the following section, participants working in First Nations organizations and governments are identified by an alphanumerical code beginning by the letters FN. Employees working for Alberta Health are identified by AH, and those from Alberta Health Services by AHS. Federal employees are identified by $\mathrm{HC}$ for Health Canada. The 25 interviews represent over 26 hours of audio-recording and 700 double-spaced pages of transcripts.

\section{Findings}

\section{Preconditions to Collaboration}

While we were interested in the "action(s) to change behaviours" identified in the TRC's $(2015, \mathrm{p} .7)$ definition of reconciliation, we anchored our data gathering and analysis on Gray's (1985) preconditions to collaboration. These included identification of a requisite number of stakeholders; positive beliefs about expected outcomes; recognition of interdependence; perceptions of legitimacy amongst stakeholders; having a legitimate, skilled convenor; and shared access and power. As we will demonstrate below, some of the preconditions identified by Gray were useful in describing our context (e.g., identification of stakeholders), while others were not perceived as particularly relevant by participants (e.g., legitimate, skilled convenor). Furthermore, the inclusion of historical relationships within legitimacy may fail to highlight the importance of this element in collaboration among First Nations, the federal government, and the provincial government.

\section{Identification of Stakeholders}

Gray's (1985) first precondition is the ability to identify the participants "whose expertise is essential to building a solution" (p. 918). There was consensus amongst participants as they identified the partnering organizations in First Nations health care: First Nations of Treaty No. 6, Treaty No. 7, and Treaty No. 8, Alberta Health, Alberta Health Services, and FNIHB-AB. Both federal and provincial ministers provided letters of support in February 2015 (Ambrose, 2015; Mandel, 2015). A First Nation participant said:

We didn't really get a signed commitment from those three [Health Co-Management] chiefs saying, we're going to strive to work to get an agreement. They never ever signed... And that's where it's going to get derailed. (FN02)

Another First Nation participant questioned the readiness of some First Nations organizations and governments: 
I think you have some groups out there who are ready, and you have some groups who are not ready ... Do we collectively have enough strength there and vision and support to move things forward? (FN08)

These statements were made in the fall of 2015, more than two years before the Assembly of Treaty Chiefs' decision to halt all trilateral discussions.

As a participant in this process, I (N.L.) was aware that the membership of the Joint Action Health Plan Working Group and Steering Committee remained fluid because some partnering organizations did not formally appoint representatives, staff turnover occurred, and some regular attendees identified themselves as observers rather than participants. Some participants shared limitations regarding their ability to speak and make decisions on behalf of their organizations (AH02, AHS01), while others signalled the importance of members reporting back to their organizations and the communities they represent (FN05, FN10).

Therefore, participants' input aligned with issues identified in the collaboration literature: ill-defined membership list, ambiguity about decision-making authority among members, representativeness of stakeholders, and challenges in reporting back to thinly institutionalized organizations ${ }^{2}$ (Huxham \& Vangen, 2000; Westley \& Vredenburg, 1991). The main issues with representativeness were that First Nations participants were rarely formally appointed and had multiple accountabilities - to themselves, to the collective, to their organization, and to the communities they represent. Colleagues from all partnering organizations also indicated feeling limited in their ability to speak and make decisions on behalf of their organizations. This answers the question, who is at the table? However, Gray (1985) asked not only who participates but "whose expertise is essential to building a solution" (p. 918). To answer this question, we consider the participants' input regarding relationships among First Nations, the federal government, and the provincial government.

\section{Relationships Between First Nations and the Federal Government}

A federal participant acknowledged "the federal government's jurisdictional role as a representative of the Crown with respect to being a treaty partner" (HC01). However, First Nations participants questioned the willingness of the federal government to honour the treaties. A First Nation participant indicated:

They're [federal government] not willing to step up to their side of the Treaty and honour the Treaty Right to Health and deliver the services to First Nations the way they should. (FN06)

Another First Nation participant shared that the 1979 Indian Health Policy limits the ability to support better health outcomes and health care for First Nations (FN01). First Nations participants shared that frequent changes in terms of policy and organizational changes negatively impact their ability to build and maintain relationships with government partners (FN08, FN14). Participants also referred to existing collaborations, such as the Health Co-Management Agreement, which they described as an

\footnotetext{
${ }^{2}$ Westley and Vredenburg (1991) defined thinly institutionalized as "lack[ing] a developed internal hierarchy and a central authority" (p. 72).
} 
administrative agreement that enabled First Nations and the federal government to co-manage FNIHB$\mathrm{AB}$ funding (FN03). A federal participant highlighted its importance in terms of relationships:

Co-management goes a long way to help facilitate a lot of those conversations. We are decades ahead as far as having an established working relationship with communities. We need to nurture and honour that relationship. (HC03)

Some federal and provincial participants were more optimistic after the 2015 elections, believing that they may have a more supportive political environment (AH03, AHS01, HC01, HC02).

\section{Relationships Between First Nations and the Provincial Government}

First Nations participants expressed their and/or their colleagues' concerns about the involvement of the provincial government and its potential impact on the Treaty Right to Health (FN03, FN08). A First Nation participant who sought to establish stronger relationships with the provincial government indicated that she had been told by First Nations colleagues that she was sleeping with the government and was accused of selling out their Treaty Rights (FN03). Acknowledging these concerns, provincial and federal participants shared:

There has to be an acknowledgment of the development of the treaties and what those treaties mean for communities and how working with the province might ... jeopardize the responsibilities of the federal government to those treaties [and] to fulfill those Treaty Rights. (AH02)

Some [First Nations] might hold very firm that they don't even want to have a conversation with the province, because they feel like the province compromises their Treaty Right to Health. They really feel that the federal government represents the Crown and that special relationship with the Crown through Treaty. (HC03)

Some First Nations participants (FN06, FN15) flagged the poor track record of the provincial government as a partner:

The province doesn't have a good history of inclusion of First Nations people or First Nations organizations in their delivery model systems. (FN06)

I think that's something we keep missing the mark is, we sit around those tables, and nobody really says from the provincial side, "This is how—exactly how we can help," right. I think it would be good to know that from the outset. (FN15)

We're all Albertans at election time, but once the election is over, then all of a sudden we're referred back to being First Nations again, and the province doesn't want to come on reserve and help us out. (FN06)

Some First Nation participants saw this relationship more positively. A First Nation participant said: "Alberta Health Services now is ready to engage with us" (FN13), while another referred to the 
excitement of AHS workers "to see things change" (FN14). Another First Nation participant highlighted his increased work with the provincial government saying:

When I first came in [as health director], I did all of my work with MSB and Health Canada. And now maybe $10 \%$ of my work is with Health Canada and $90 \%$ is with the province. (FN08)

Even among First Nations participants supporting provincial involvement, at least one questioned whether AHS operates as a service delivery agency rather than a "political body" (FN02).

As Alberta Health and Alberta Health Services only provided in-kind support to the Joint Action Health Plan, some participants questioned their commitment (FN02, HC02). Provincial participants explained their inability to contribute financially due to "challenging economic times" (AH03), or due to the implicit understanding that provincial funding serves all Albertans rather than specific groups (AH03, AHS02). They hoped that a solid proposal could be supported (AH03) or that an equity lens would be helpful in accessing funding (AHS02). Unfortunately, these items were never specified within the Joint Action Health Plan or the interviews and no provincial funding was ever provided. Despite misgivings about provincial participation, some First Nations participants valued their participation (FN03, FN08), indicating "we cannot address health without the province being at the table" (FN03).

\section{Relationships Between Federal and Provincial Governments}

A provincial participant acknowledged barriers within the context of federal and provincial relationships:

On the provincial side, I think the barriers are, well, the federal government has to fund some of this. You have to work out funding relationships, because if the province just goes in and funds, then the feds will just back out, and that [there] will be floodgates, and we won't be able to afford it-there are so many fears. (AH01)

The sentiment expressed is neither new nor limited to Alberta. Blackfoot scholar Leroy Little Bear and his colleagues (1992) wrote:

Although the Constitution permits the provincial governments to extend any services to Indians that the federal government allows (and the federal government has been extremely permissive in this regard), all provinces are uniformly reluctant to accept financial responsibility for services to Indians within their boundaries. In part this explains why Indian bands are still outside the bulk of provincial programs. (p. xiii)

On a more positive note, a federal participant interviewed shortly after the 2015 elections highlighted similarities between the new federal and provincial governments:

We both seemingly have some common vision, some common commitments, similar mandates in a lot of ways. Both recognize that we need to do better in terms of First Nation health outcomes. (HC02)

Therefore, participants were able to identify stakeholders "whose expertise is essential to building a solution" (Gray, 1985, p. 918); however, this did not always result in a consensus about who should 
participate in the process. While they agreed on the participation of First Nations and FNIHB-AB, they expressed ambivalence about provincial involvement, which influenced the assessment of legitimacy among partners.

\section{Stakeholders' Expectations About Positive Outcomes}

In defining stakeholders' expectations about positive outcomes, Gray (1985) asserted that participating organizations "must believe that collaboration will produce positive outcomes" (p. 920). Participants outlined many expectations in terms of positive outcomes. First, participants identified the need to improve health outcomes among First Nations (AH01, AH03, FN04, AHS03, HC03, FN11) and First Nations health care (FN02, FN03, AH03, AHS01, AHS03, FN06, FN08, FN10, HC03, FN11). A First Nation participant described it as follows:

We are fighting and moving for future generations, and ... the focus up to now is really about improving access, about improving health care for those future generations. (FN08)

Second, participants highlighted the need for greater engagement of First Nations individuals, organizations, and governments in health care delivery (AH01, FN03, AHS01, AHS03, FN13, HC03). A First Nation participant said:

We cannot expect the federal government and the federal representatives to continue to always speak on our behalf. We have a voice. We should be able to bring it to the table as well. (FN03)

The participant added:

This is where we bring the voice to the ears who can make some changes, whether it be to policy, whether it [be] within their systems, whether it be addressing communications, whether it be addressing education, cultural competency, safety, and not only just for First Nations but every culture that comes through their doors. (FN03)

Other participants referred to the establishment of working relationships between all parties (HC01, FN08), the establishment of more collaborative approaches (HC03, AH04), and a more formal partnership that would lead to a memorandum of understanding (FN14).

Third, participants highlighted the importance of responding to community needs (FN02, FN03, AH02, AHS01, AHS03, FN13), as a First Nation participant said, "[First Nations] communities have to lead the process" (FN08). Further, participants shared expectations for policy and legislative changes (FN03, FN12, FN13, AHS02), as well as more evidence-based approaches informed by health information (FN01, AH02).

In summary, there was a broad consensus amongst participants as they outlined their expectations for positive outcomes. However, these remained at a relatively high level without agreement on next steps, which was acknowledged by a participant who said, "We can agree with all of it, because it's so high level, and it doesn't really get into the details" (AHS03). These outcomes were also ambitious considering the 18-month timeline of the Joint Action Health Plan. 


\section{Degree of Recognized Interdependence}

Gray (1998) wrote, "the recognition by stakeholder groups that their actions are inextricably linked to the actions of other stakeholders is a critical basis for collaboration" (p. 921). Members of the Working Group described the Joint Action Health Plan as the only trilateral health table in Alberta and as an opportunity to "chang[e] our narrative, chang[e] our perspective on what relationships should be" (AH04).

Many participants are involved in other collaborations, which led First Nations participants to acknowledge colleagues who, through their work on other projects, had the ability to help other initiatives (FN08, FN15). Others flagged the benefit of other collaborations such as access to specialists on reserve (FN08) and work with local hospitals to find solutions as issues arose (FN02). However, not all collaborations are viewed positively: One participant referred to "lip service" (FN04). She flagged limited engagement and fear of engagement by government partners. This participant shared her frustrations in terms of her engagement with the provincial government and one of the Alberta Health Services' zones, indicating that she had ceased to attend some of the meetings. She also shared her concerns regarding engagement saying: "Don't build a bridge and ask me about brass or silver knobs, ask me if I think a bridge is a good idea." Provincial participants highlighted the contribution of the AHS Wisdom Council (AHS02, AHS03) in supporting increased cultural competency. Also, a federal participant identified the management of a crisis, the 2013 floods in southern Alberta, as having positively contributed to relationships between partnering organizations:

After that there was a different feeling, different vibe. It was the first time ... the province put big money and actually crossed that imaginary line in the sand. (HCO2)

So, participants recognized increased interdependence between partnering organizations.

\section{Legitimacy of Stakeholders}

Gray (1985) defined a legitimate stake as "the perceived right and capacity to participate in the developmental process" (p. 921), which includes historical relationships and prevailing norms in collaboration. Participants talked abundantly about the relationships between partnering organizations and described a complex environment that went beyond health care collaboration.

\section{Assimilation, Colonization, and Oppression}

Participants talked of assimilation, colonization, and oppression (FN01, AH02, FN06, FN07, FN11, FN15). A First Nation participant said, "I'm not a big fan of that assimilation policy, and that's exactly what I see" (FN06), before adding "they [federal government] want to assimilate us" (FN06). He also indicated that "the underlying assumption that Canada is a colonizing state is not recognized" (FN06). He further compared the relationship between First Nations and federal and provincial governments as an abusive relationship:

It's like a relationship. You cheat on me a couple times, even if I go back with you ... I'm not entirely going to trust you. And that's where I'm seeing there's a lot of abuse between the federal government, provincial government, on First Nations. First Nations have no choice. We're still 
having to go back to this partner, these abusive partners. And we keep hoping. So with the new Liberal government now we get slapped instead of being punched. But the abuse will still continue. (FN06)

Other participants described the treatment of First Nations since contact:

That's probably the greatest understatement of all time [to say] that we haven't been treated fairly but it does a lot to a people ... in a very negative way. (FN15)

This is also congruent with Indigenous literature: As Métis scholar Carrie Bourassa and her colleagues (2004) wrote, "at a fundamental level, we understand that the colonization processes that began many years ago and continue today have material and social consequences that diminish access to social determinants of health for both Aboriginal men and Aboriginal women” (p. 27).

A First Nation participant questioned the decision to maintain policies that are causing harm (FN01), while indicating that "historical harms aren't from contact because historical harms continue as [of] yesterday" (FN01). This ongoing colonization has been identified by Indigenous authors and scholars (Alfred, 2009; Bourassa et al., 2004; Corntassel, 2009, 2012; Coulthard, 2014; Fanelli, 2013; Little Bear et al., 1992). Further, the TRC's (2015) Call to Action 18 calls upon governments to acknowledge the impact of government policies and legislations on the health status of Indigenous Peoples.

\section{The Treaties as the Foundation to Our Relationship}

In interviews, participants stressed the importance of the treaty relationship between First Nations and the Crown, highlighting the Medicine Chest Clause in Treaty No. 6 (AH02, AHS01, FN01, FN02, FN03, FN08, FN12, HC01). First Nations participants outlined an understanding of the treaty relationship that is congruent with Indigenous literature.

First Nations take a stance upholding the Treaty and not doing anything to delineate or move away from the treaty relationship and always bringing that to the table that it supersedes the relationship that the federal government has with First Nations because their treaty is not with ... the federal government it's with the Crown ... before this country was even created. (FN01)

The federal government does not want to live up to their side of the Treaty. They're willing to ignore it. (FN06)

It's a battle of words, English words. That's what it boils down to. It's a battle of what the government actually puts in black and white, is where the battleground is and always has been, with the intent of, basically in our view trying to get out of the obligation of the treaties. (FN03)

Indigenous and non-Indigenous scholars also criticize the federal government's approach to the treaties (Alfred, 2009; Borrows, 2002; Cardinal, 1999; Dickason \& Newbigging, 2010; Saul, 2014; Venne, 1997, 1998, 2007). Cree scholar Sharon Venne (1997) outlines that "the written text expresses only the Government of Canada's view of the treaty relationship: it does not embody the negotiated agreement" (p. 173). A federal participant outlined the negative legacy that impacts our discussions as follows: 
There is a very significant negative legacy that comes into play with respect to the Crown and Treaty First Nations relationship ... unless we can actually address some of those barriers in the context of the Joint Action [Health] Plan, it definitely will impede the overall effectiveness that we can have in the Joint Action [Health] Plan. (HC01)

A provincial participant (AHS01) shared that awareness of treaties was limited within Alberta Health Services while flagging the opportunity provided by the provincial government's commitment for renewed relationships.

\section{Limited Trust, Lack of Trust, Mistrust, and Distrust}

As First Nations participants shared their perceptions of the relationship among First Nations, the federal government, and the provincial government, they referred to "limited trust," "lack of trust," "mistrust," and "distrust." First Nations participants shared their lack of trust as follows:

The trust is not there, and, quite frankly, I don't think the federal and provincial governments are coming in all honesty with their full agendas available to First Nations people and organizations. (FN06)

Until we reach that common ground ... it is going to be us versus them, because we're always in a mindset that the government has ulterior motives, and it's hidden between the lines in their black and white... And that creates a trust factor, we'll say. (FN03)

The trust level was so low that we didn't want to be even seen in the same room. (FN03)

First Nations participants also referred to mistrust (FN02, FN04, FN05, FN13) and distrust (FN06, FN10, FN13) towards federal and provincial governments. In describing distrust, a participant indicated:

I think distrust is a really strong word, but I'm not sure of another word to use. But just kind of questioning or wondering what the agenda or the motives or the actions are from either Alberta Health or from FNIHB themselves, whether or not they're really working in the best interests of First Nations. (FN10)

Participants working for federal and provincial governments acknowledged the limited trust (AH04, AHS03, HC02) and one of them shared that "based on history, I think that's really quite reasonable" (AHSO3).

\section{Racism and Discrimination}

First Nations participants shared their experience with racism and discrimination. At a personal level, racism was identified within the context of our collaborative discussions and perceived as limiting our ability to work together:

And just being [a] First Nation woman, myself, I have seen over time, and I've experienced individuals who are a bit racist. You can see it in their mannerisms, the way they look at you, the tone of their voice. And there have been individuals like that at the other end of the table, is what 
I [have] seen and I observed. But I didn't say anything. However, over time I notice that they drop off the table, because they don't have any interest in trying to address the issue of systemic racism within the system itself when they have representatives who are. It's very, very difficult. (FN03)

At a system level, a First Nation participant linked it to concerns regarding sustainability of First Nations health care which will segue to the next section on inequities of resources:

I don't like to throw the race card out there, but I really like to try and believe that we're treated like all Canadians and all Albertans, but we're clearly not in service delivery because we are not being protected ... We are being delivered a service which has no sustainability. (FN01)

\section{Inequities in Resource Allocation}

First Nations participants were concerned about the lack of capacity of First Nations organizations (FN03, FN04, FN13, FN06, FN15). One participant said:

We could do so much more, so much more if we are just provided the adequate capacity to do it. (FN03)

In identifying concerns regarding equity of resource allocations, First Nations participants did not limit their comments to the resources required for participating in the Joint Action Health Plan, nor to the funding related to health care. A First Nation participant began by sharing: "We're being deliberately underfunded," adding:

If we would have had access to the resources that were taken out of Treaty 8 territory at a rate where we could fund our own health care, education, child welfare, a lot of these issues may have been addressed already, because our capacity would have been the same. However, all the money gets sucked out of Treaty 8 , sent to the federal government, who then doles out a pittance to Treaty 8 First Nations, and the rest of the money is spent to keep the rest of Canada going. (FN06)

First Nations participants across the three treaty areas (FN02, FN03, FN06, FN07, FN12) referred to perceptions of Canadians regarding First Nations and taxation. They indicated that they pay taxes and that statements to the contrary are not accurate. A First Nation Elder said:

I think that the Indigenous people of this great land are the biggest taxpayers in the country by virtue of the wealth of this country. (FN07)

A second First Nation participant shared that First Nations have significantly contributed to the development of Canada and referred to accusations of not paying taxes as a reason to deny services:

Accusations and everything that we don't pay taxes, we don't deserve anything kind of attitude. But, in fact, we paid up front for all these services. We didn't even get $1 \%$ of the land in total of Canada, and look at the billions and trillions of dollars now that they're receiving. And we get peanuts. (FN03) 
In summary, there are concerns regarding the legitimacy of stakeholders when using Gray's (1985) two criteria of right and capacity. Participants agreed that the federal government and First Nations have the right to participate; however, the involvement of the provincial government and agencies was questioned. In terms of capacity, participants highlighted the capacity of federal and provincial governments while sharing that First Nations capacity was much more limited due to a lack of sustainability and insufficiency of funding.

\section{Convenor Characteristics}

Among the key preconditions identified by Gray (1985) are the convenor characteristics, which she defines as one "who initiates collaborative problem solving [and] has a critical impact on its success or failure" (p. 923). While Gray stresses the importance of a skilled convenor, this element is not apparent based on the input received from participants. Invitations to participate in the Joint Action Health Plan were issued by the federal Senior Steering Committee member. Some meetings were facilitated by an external facilitator, while others were facilitated or co-chaired by staff from partnering organizations. Some First Nations participants highlighted the contribution of Elders to discussions (FN03, FN11, FN13), while others talked of the contributions of influential First Nations colleagues (FN08, FN15). So, while Gray signals the importance of the convenor, participants did not identify any convenors to the Joint Action Health Plan. It is unclear whether the Joint Action Health Plan would have benefited from a convenor or if this precondition is not culturally relevant as participants answered this question by referring to more than one individual.

\section{Shared Access and Power}

Collaboration literature stresses the importance of power and its distribution among partnering organizations (Foster-Fishman et al., 2001; Gray, 1985; Mayo, 1997). Participants identified power imbalances (AH02, FN01, FN11) and the need to level the playing field:

In trying to work together without acknowledging the history and acknowledging that those imbalances of power exist, there is the potential for us to not [be] walking in the same direction as we try to move forward. (AH02)

We don't understand the significance of the power of information. And we don't understand that since time of contact and since before contact that Western thinkers have been driven, their data have driven policy, policy change, and policy development. We haven't quite grasped that concept because data have not been available to us it's only been taken from us and what we have perceived as being used against us. (FN01)

Rather than referring to power, two First Nations participants talked of control:

We have given the government too much control over us... We have given the medical community too much control over us ... it would be better overall if we go back to doing things for ourselves. (FN07)

The Elders are telling us we have to take control of our own destiny, our own life. We have to get [for] lack of a better phrase, our house in order. We have to know who we are, and we have to 
take control of our lives, not feel that we're under the Indian Act, to put it bluntly, but that's not the end-all that governs us. We have to govern ourselves and get away from this mentality of paternalism. We're nobody's child. We're adults. We have to take control of our own lives. (FN11)

In summary, participants identified concerns regarding shared access and power imbalances among First Nations, the federal government, and the provincial government in terms of information and resources that extends beyond the Joint Action Health Plan.

\section{Discussion}

In Table 1, we provide a summary of how participants assessed the preconditions to collaboration. While our focus was on the Joint Action Health Plan, this summary highlights that participants provided a much broader perspective encompassing relationships among First Nations, the federal government, and the provincial government, as well as between First Nations and settler society in Canada. Among these preconditions, Gray (1985) indicated that "unless some consensus is reached about who has a legitimate stake in an issue and exactly what that joint issue is, further attempts to collaboration will be thwarted" (p. 917).

\section{Joint Issues}

Participants demonstrated a high level of consensus as they shared expectations about positive outcomes including improving First Nations health outcomes and health care; greater engagement of First Nations individuals, organizations, and governments; establishing working relationships between all parties; responding to community needs including through policy and legislative changes; and using more evidence-based approaches informed by health information. Would this high-level consensus meet Gray's (1985) requirement of a "joint issue?" Probably not. First, while progress could be made on some of these outcomes, they were not achievable within the 18-month timeline initially established. Second, even though the two Joint Action Health Plan committees met regularly until January 2018 and talked about the need to narrow the "joint issue(s)," this was never achieved prior to the February 2018 decision of the Assembly of Treaty Chiefs to halt all trilateral discussions, which led to the abandonment of the Joint Action Health Plan. Does this mean that all this collaborative work was for nothing? No, the ethical space framework that was developed became part of the Memorandum of Understanding on Implementation of Jordan's Principle (First Nations Health Consortium, Her Majesty the Queen in Right of Canada, \& Her Majesty the Queen in Right of Alberta, 2018). Participants indicated having developed a better understanding of each other, their respective organizations, and other collaborations. The Joint Action Health Plan was a forum where participants shared their collaborative endeavours to improve access to and/or quality of health care for First Nations. In terms of practical implications and considering the successes shared by participants, it appears that collaboration is easier (but by no means easy) at lower levels of aggregation, as clarifying a joint outcome may be easier to achieve (e.g., improving access to physicians and other providers or seeking better services in a local hospital). These collaborations were perceived as paving the way for further collaboration and participants highlighted the need to create a mechanism to share information on health care collaboration among First Nations, the federal government, and the provincial government. Province-wide initiatives such as the Joint Action Health Plan were perceived as desirable for their ability to generate more systemic approaches to 
programs, policies, and relationships among First Nations, the federal government, and the provincial government. However, such initiatives are more challenging in light of the negative legacy of relationships between First Nations and federal and provincial governments, as well as the broader scope required to acknowledge the needs of many partners, which further impacts the capacity to deliver in a timely manner and endangers legitimacy.

\section{Table 1. Summary of Preconditions to Collaboration}

\begin{tabular}{lll}
\multicolumn{1}{c}{ Preconditions to Collaboration } & \multicolumn{1}{c}{ Feedback Summary } \\
\hline $\begin{array}{l}\text { Identification of a requisite number } \\
\text { of stakeholders }\end{array}$ & $\bullet \begin{array}{l}\text { Broad consensus around the participation of First } \\
\text { Nations of Treaty No. 6, Treaty No. 7, and Treaty No.8, } \\
\text { and FNIHB-AB }\end{array}$
\end{tabular}

- First Nations participants are ambivalent towards provincial involvement

Positive beliefs about expected outcomes

Recognition of interdependence

Perceptions of legitimacy amongst stakeholders

Legitimate skilled convenor

Shared access and power
- High-level consensus on expected outcomes impacting ability to identify deliverables

- Increasing recognition of interdependence

- Historical relationships between partnering organizations limits perceptions of legitimacy

- First Nations participants were concerned over sustainability and sufficiency of funding for First Nations organizations

- No legitimate, skilled convenor was identified

- Lack of shared access and power imbalances among collaborators

\section{Legitimacy}

For Gray (1985), legitimacy includes two key elements: the right and capacity to participate. Participants identified a long list of concerns regarding the legitimacy of partners including:

- Canada's ongoing assimilation, colonization, and oppression of First Nations;

- Canada's failure to fully acknowledge the treaties as the foundation to its relationship with First Nations;

- Limited trust, lack of trust, mistrust, and distrust of First Nations towards federal and provincial governments as a result of assimilation, colonization, and oppression, as well as failure of the Crown to honour treaties;

- Racism and discrimination of First Nations at personal and systemic levels; and 
- Inequities in resource allocations between First Nations and federal and provincial governments.

These legitimacy concerns are serious and underscore the collaboration challenges among First Nations, the federal government, and the provincial government. These concerns suggest that collaboration cannot occur without reconciliation, which includes "awareness of the past, acknowledgement of the harm that has been inflicted, atonement for the causes, and action to change behaviour" (Truth and Reconciliation Commission of Canada, 2015, p. 6). In terms of practical considerations, legitimacy concerns require the federal and provincial governments to move beyond lip service and references to renewed relationships and reconciliation. Participants in the process must demonstrate a true commitment to collaboration, which would include working with First Nations organizations and governments based on the priorities identified by First Nations. In terms of intergovernmental collaboration, this work should lead to questioning and revising current legislations, policies, processes, and approaches. It also highlights the need to better support the management of inevitable conflicts as First Nations, the federal government, and provincial governments seek to develop and enhance collaboration.

\section{Conclusion}

Approaching this research as practitioner-scholars, we understood that collaboration is not easy. In our search for practical approaches to enhance collaboration, we initially focused on the second phase of collaboration (processes) and the opportunity to enhance the four elements of collaborative capacity: member capacity, relational capacity, organizational capacity, and programmatic capacity. However, as we conducted interviews, we realised that we had underestimated the importance of the preconditions to collaboration among First Nations, the federal government, and the provincial government. This led to this article's question: How are efforts to collaborate and engage in reconciliation thwarted by unattended preconditions?

Based on the information gathered, we identified social, political, cultural, legal, and jurisdictional aspects related to collaboration among First Nations, the federal government, and the provincial government. Arguably mid-level public servants have limited ability to address the legal and jurisdictional aspects of collaboration. However, we believe they have an important role to play in the complex web of relationships among First Nations, the federal government, and provincial governments. From our research, we identify the following recommendations:

a. Collaboration needs to be led by First Nations based on their needs rather than being dictated by federal government and/or provincial government agendas.

b. Federal and provincial public servants should heed the TRC's (2015) Call to Action 57, which calls for more education (including about the history of Indigenous Peoples) and training of public servants "in intercultural competency, conflict resolution, human rights, and anti-racism” (p. 271). Further, based on participants' input, we also recommend learning more on the Treaty Right to Health and the Medicine Chest Clause; health from a First Nations' perspective; the broader context of relationships between First Nations and federal and provincial governments, as well as between First Nations and settler society in Canada; and Indigenous worldviews. 
c. Mid-level public servants need to understand that their conduct in collaboration impacts other collaborations, which highlights the importance of conducting oneself honourably. As a participant indicated organizational trust cannot exist without personal trust (AH04).

In conclusion, health care collaboration among First Nations, the federal government, and the provincial government is not a panacea but an opportunity for "actions to change behaviour" that will ensure that reconciliation and renewed relationships are more than words.

\section{References}

Alberta Government. (2015). Alberta Speech from the Throne: June 15, 2015-First session of the twenty-ninth legislature. http://www.alberta.ca/release.cfm?xID=38187AFEDC714-0E6A6F93-BC6A2C3B767D9AD9

Alfred, T. (2009). Wasáse: Indigenous pathways of action and freedom. University of Toronto Press.

Ambrose, R. (2015). Letter to the Health Co-Management Committee [unpublished].

Assembly of First Nations Quebec-Labrador (AFNQL). (2014). First Nations in Quebec and Labrador's research protocol. https://achh.ca/wp-content/uploads/2018/07/Protocol_FNResearch-Protocol-in-Labrador-and-Quebec.pdf

Battiste, M. (2005). Indigenous knowledge: Foundations for First Nations. World Indigenous Nations Higher Education Consortium-WINHEC Journal, 1, 1-12.https://gov.viu.ca/sites/default/ files/indegenousknowledgepaperbymariebattistecopy.pdf

Borrows, J. (2002). Recovering Canada: The resurgence of Indigenous law. University of Toronto Press.

Bourassa, C., McKay-McNabb, K., \& Hampton, M. (2004). Racism, sexism, and colonialism. Canadian Woman Studies, 24(1), 23-29.

Brant Castellano, M. (2004). Ethics of Aboriginal research. Journal of Aboriginal Health, 1(1), 98-114.

Brede, F. (2008). The Commission on the Future of Health Care in Canada: A case study of Aboriginal health. In K. Knopf (Ed.), Aboriginal Canada revisited (pp. 50-71). University of Ottawa Press.

Butterfield, K. D., Reed, R., \& Lemak, D. J. (2004). An inductive model of collaboration from the stakeholder's perspective. Business and Society, 43(2), 162-195. https://doi.org/ $\underline{10.1177 / 0007650304265956}$

Canada Governor General. (2015). Making real change happen: Speech from the Throne to open the first session of the forty-second Parliament of Canada. https://www.canada.ca/en/privycouncil/campaigns/speech-throne/making-real-change-happen.html

Cardinal, H. (1999). The unjust society. Douglas \& McIntyre Ltd. 
Cardinal, H., \& Hildebrandt, W. (2000). Treaty Elders of Sakstachewan: Our dream is that our peoples will one day be clearly recognized as nations. University of Calgary Press. https://doi.org/ 10.2307/j.ctv6gqwq3

Co-Management. (1996). First Nations and MSB Alberta Region Envelope: Co-Management Agreement. Author.

Co-Management. (2014). Joint Action Plan to improve the health of First Nations in Alberta. Author.

Constitution Act, 1867, 30 \& 31 Victoria, c. 3 (U.K.). https://laws-lois.justice.gc.ca/eng/ const/page-1.html

Corntassel, J., Chaw-win-is, \& T'lakwadzi. (2009). Indigenous storytelling, truth-telling, and community approaches to reconciliation. ESC: English Studies in Canada, 35(1), 137-159. https://doi.org/10.1353/esc. 0.0163

Corntassel, J. (2012). Re-envisioning resurgence: Indigenous pathways to decolonization and sustainable self-determination. Decolonizaton: Indigeneity, Education and Society, 1(1), 86101.

Coulthard, G. S. (2014). Red skin, white masks: Rejecting the colonial politics of recognition. https://doi.org/10.5749/minnesota/9780816679645.001.0001

Creswell, J. (2008). Educational research: Planning, conducting, and evaluating quantitative and qualitative research (3rd ed.). Pearson Education Inc.

Dickason, O. P., \& Newbigging, W. (2010). A concise history of Canada's First Nations (2nd ed.). Oxford University Press.

Fanelli, C. (2013). Austerity and Aboriginal communities: An interview with David Newhouse. Alternate Routes: A Journal of Critical Social Research, 24, 207-214.

Fawcett, S. B., Paine-Andrews, A., Francisco, V. T., Schultz, J. A., Richter, K. P., Lewis, R. K., Williams, E. L., Harris, K. J., Berkley, J. Y., Fisher, J. L., \& Lopez, C. M. (1995). Using empowerment theory in collaborative partnerships for community health and development. American Journal of Community Psychology, 23(5), 677-697. https://doi.org/10.1007/ $\underline{\mathrm{BF} 02506987}$

First Nations Health Consortium, Her Majesty the Queen in Right of Canada, \& Her Majesty the Queen in Right of Alberta. (2018). Memorandum of understanding on implementation of Jordan's Principle in Alberta. https://open.alberta.ca/dataset/4b895aa2-779f-4b77-a2f8$\underline{8 \mathrm{a} 7 \mathrm{~d} 89633 \mathrm{bda} / \mathrm{resource} / \mathrm{ec} 7 \mathrm{da} 410 \text {-e8f2-4132-a722-344bf776128b/download/jordans- }}$ principle-mou-20181109.pdf

First Nations Information Governance Centre. (2014). Ownership, Control, Access and Possession: The path to First Nations information governance. https://fnigc.inlibro.net/cgibin/koha/opac-imageviewer.pl?biblionumber $=7$ 
Foster-Fishman, P. G., Berkowitz, S. L., Lounsbury, D. W., Jacobson, S., \& Allen, N. A. (2001). Building collaborative capacity in community coalitions: A review and integrative framework. American Journal of Community Psychology, 29(2), 241-261.

Gaudet, J. C. (2014). Rethinking participatory research with Indigenous Peoples. Journal of the Native American and Indigenous Studies Association, 1(2), 69-88. https://doi.org/10.5749/ natiindistudj.1.2.0069

Government of British Columbia, Government of Canada, \& the Leadership Council representing the First Nations of British Columbia. (2006). Transformative Change Accord. https://www2.gov.bc.ca/assets/gov/british-columbians-our-governments/indigenouspeople/aboriginal-peoples-documents/transformative change accord.pdf

Government of Canada. (1969). Statement of the Government of Canada on Indian Policy (The White Paper, 1969). http://www.aadnc-aandc.gc.ca/eng/1100100010189/1100100010191

Gray, B. (1985). Conditions facilitating interorganizational collaboration. Human Relations, 38(10), 911-936. https://doi.org/10.1177/001872678503801001

Gray, B., \& Purdy, J. (2018). Collaborating for our future: Multistakeholder partnerships for solving complex problems. https://doi.org/10.1093/oso/9780198782841.001.0001

Hardy, C., \& Phillips, N. (1998). Strategies of engagement: Lessons from the critical examination of collaboration and conflict in an interorganizational domain. Organization Science, 9(2), 217230. https://doi.org/10.1287/orsc.9.2.217

Hawthorn, H. B. (1967). A survey of the contemporary Indians of Canada: A report on economic, political, and educational needs and policies - Part 1. http://caid.ca/HawRepla1966.pdf

Health Canada. (1979). Indian Health Policy. http://caid.ca/IndHeaPol1979.pdf

Health Canada. (1999). Ten years of health transfer First Nation and Inuit control. https://web.archive.org/web/20070220013037/http://www.hc-sc.gc.ca/fnihspni/pubs/agree-accord $/ 10$ years ans trans $/ 3$ transfert e.html

Health Canada. (2012). Alberta on-reserve health services and programs, 2012 (H34-256/2012E). http://publications.gc.ca/collections/collection_2012/sc-hc/H34-256-2012-eng.pdf

Hocevar, P. S., Jansen, E., \& Fann Thomas, G. (2007, May 16-17). Developing collaborative capacity: A diagnostic model. In The proceedings of the fourth annual Acquisition Research Symposium of the Naval Postgraduate School (pp. 252-259). https://calhoun.nps.edu/bitstream/handle/ 10945/406/NPS-AM-07-003.pdf?sequence $=1$ \&isAllowed $=\mathrm{y}$

Huxham, C., \& Vangen, S. (2000). Ambiguity, complexity and dynamics in membership of collaboration. Human Relations, 53(6), 771-805. https://doi.org/10.1177/ $\underline{0018726700536002}$ 
Indian Act-An Act to amend and consolidate the laws respecting Indians, S.C. 1876, c. 18. https://www.aadnc-aandc.gc.ca/eng/1100100010252/1100100010254

Kovach, M. (2012). Indigenous methodologies: Characteristics, conversations and contexts. University of Toronto Press.

Little Bear, L., Boldt, M., \& Long, J. A. (1992). Pathways to self-determination: Canadian Indians and the Canadian state. University of Toronto Press.

Logsdon, J. M. (1991). Interests and interdependence in the formation of social problem-solving collaborations. The Journal of Applied Behavioral Science, 27(1), 23-37. https://doi.org/ $\underline{10.1177 / 0021886391271002}$

Mandel, S. (2015). Letter to Chief Alexis, Chief Threefingers, Chief WeaselHead and Chief Courtoreille [unpublished].

Martin, D. E., Thompson, S., Ballard, M., \& Linton, J. (2017). Two-eyed seeing in research and its absence in policy: Little Saskatchewan First Nation Elders' experiences of the 2011 flood and forced displacement. The International Indigenous Policy Journal, $8(4)$. https://doi.org/ $\underline{10.18584 / \text { iipj.2017.8.4.6 }}$

Mayo, M. (1997). Partnerships for regeneration and community development: Some opportunities, challenges and constraints. Critical Social Policy, 17, 3-26.

Patrick, R. J., Machial, L., Quinney, K., \& Quinney, L. (2017). Lessons learned through communityengaged planning. The International Indigenous Policy Journal, $8(2)$. https://doi.org/ 10.18584/iipj.2017.8.2.7

Roberts, N. C., \& Bradley, R. T. (1991). Stakeholder collaboration and innovation: A study of public policy initiation at the state level. The Journal of Applied Behavioral Science, 27(2), 209-227. https://doi.org/10.1177/0021886391272004

Royal Commission on Aboriginal Peoples. (1996). Report of the Royal Commission on Aboriginal Peoples_Volume 1. Looking forward, looking back. http://data2.archives.ca/ e/e448/e011188230-01.pdf

Saul, J. R. (2014). The comeback: How Aboriginals are reclaiming power and influence. Penguin Canada.

Simpson, L. (2001). Aboriginal Peoples and knowledge: Decolonizing our processes. The Canadian Journal of Native Studies, 21(1), 137-148.

Simpson, L. (2011). Dancing on our turtle's back: Stories of Nishnaabeg re-creation, resurgence and a new emergence. ARP Books.

Smith, L. T. (1999). Decolonizing methodologies: Research and Indigenous Peoples. Zed Books Ltd and University of Otago Press. 
Taylor, J. L. (1985). Treaty research report: Treaty Six (1876). https://www.aadncaandc.gc.ca/DAM/DAM-INTER-HQ/STAGING/texte-text/tre6_1100100028707_eng.pdf

Treaty No. 6 between Her Majesty the Queen and the Plain and Wood Cree Indians and other Tribes of Indians at Fort Carlton, Fort Pitt and Battle River with Adhesions, 1876. https://www.rcaanccirnac.gc.ca/eng/1100100028710/1581292569426

Treaty No. 7 between Her Majesty the Queen and the Blackfeet and Other Indian Tribes, at the Blackfoot Crossing of Bow River and Fort Macleod, 1877. https://www.rcaanccirnac.gc.ca/eng/1100100028793/1581292336658

Treaty No. 8 between Her Majesty the Queen and the Cree, Beaver, Chipewyan and Other Indians of the Lesser Slave Lake area, 1899. https://www.rcaanc-cirnac.gc.ca/eng/1100100028813/ $\underline{1581293624572 \# \operatorname{chp} 4}$

Truth and Reconciliation Commission of Canada (TRC). (2015). Honouring the truth, reconciling for the future: Summary of the final report of the Truth and Reconciliation Commission of Canada. http://nctr.ca/assets/reports/Final\%20Reports/Executive_Summary_English_Web.pdf

Turpel, M. E. (1991). Aboriginal Peoples and the Canadian Charter: Interpretive monopolies, cultural differences. In R. F. Devlin (Ed.), Canadian perspectives on legal theory series: First Nations (pp. 40-73). Emond Montgomery Publications Limited.

University of Manitoba Faculty of Health Sciences. (2013). Framework for research engagement with First Nation, Métis and Inuit peoples. https://umanitoba.ca/faculties/health_sciences/ medicine/media/UofM_Framework_Report_web.pdf

Venne, S. (1997). Understanding Treaty 6: An Indigenous perspective. In M. Asch (Ed.), Aboriginal and Treaty Rights in Canada: Essays on law, equity, and respect for difference (pp. 173-207). UBC Press.

Venne, S. (1998). Our elders understand our rights: Evolving international law regarding Indigenous rights. Theytus Books Ltd.

Venne, S. (2007). Treaties made in good faith. Canadian Review of Comparative Literature, 34(1), 116.

Vowel, C. (2016). Indigenous writes: A guide to First Nations, Métis, and Inuit issues in Canada. Highwater Press.

Weick, K. E. (2001). Making sense of the organization. Blackwell Publishing.

Westley, F., \& Vredenburg, H. (1991). Strategic bridging: The collaboration between environmentalists and business in the marketing of green products. The Journal of Applied Behavioral Science, 27(1), 65-90. https://doi.org/10.1177/0021886391271004

Wilson, S. (2008). Research is ceremony: Indigenous research methods. Fernwood Publishing. 
Wood, D. J., \& Gray, B. (1991). Toward a comprehensive theory of collaboration. The Journal of Applied Behavioral Science, 27(2), 139-162. https://doi.org/10.1177/0021886391272001 